\title{
Diffusion of the e-SUS Primary Care innovation in Family Health Teams
}

\author{
Difusão da inovação e-SUS Atenção Básica em Equipes de Saúde da Família \\ Difusión de la innovación e-SUS Atención Primaria en Equipos de Salud de la Familia
}

\begin{abstract}
Talita Ingrid Magalhães Silva', Ricardo Bezerra Cavalcante', Regina Consolação dos Santos', Tarcísio Laerte Gontijo', Eliete Albano de Azevedo Guimarães', Valeria Conceição de Oliveira'
\end{abstract}

'Universidade Federal de São João Del Rei. Divinópolis, Minas Gerais, Brazil.
How to cite this article:

Silva TIM, Cavalcante RB, Santos RC, Gontijo TL, Guimarães EAA, Oliveira VC. Diffusion of the e-SUS Primary Care innovation in

Family Health Teams. Rev Bras Enferm [Internet]. 2018;71(6):2945-52. DOI: http://dx.doi.org/10.1590/0034-7167-2018-0053

Submission: 02-19-2018Ａpproval: 04-03-2018

\begin{abstract}
Objective: To analyze the diffusion of e-SUS Primary Care innovation in Family Health Teams. Method: A qualitative approach case study, based on Innovation Diffusion Theory and Technology Acceptance Model. We conducted 62 interviews and observation of professionals from Family Health Teams in six municipalities of Minas Gerais State, between March 2016 and January 2017. The data were treated through Categorical Thematic Content Analysis and, systematized, with Atlas.ti software. Results: It was verified that although the e-SUS Primary Care strategy is recognized as a technological innovation, situations predominate that weaken its acceptance as: incompatibilities with the work process; sudden deployment, poor training; work overload; resistance; and negative impacts on health care. Conclusion: The diffusion of the e-SUS Primary Care strategy as a technological innovation has presented potential situations of its rejection, conforming as challenges to be overcome.
\end{abstract}

Descriptors: Health Information Systems; Diffusion of Innovation; Primary Health Care; Family Health Strategy; Nursing Informatics.

\section{RESUMO}

Objetivo: Analisar a difusão da inovação e-SUS Atenção Básica em Equipes de Saúde da Família. Método: Estudo de caso de abordagem qualitativa, fundamentado na Teoria da Difusão da Inovação e Modelo de Aceitação de Tecnologias. Realizamos 62 entrevistas e observação de profissionais de Equipes de Saúde da Família em seis municípios de Minas Gerais, entre março de 2016 e janeiro de 2017. Os dados foram tratados através da Análise de Conteúdo Temático Categorial e, sistematizados, com o software Atlas.ti. Resultados: Verificou-se que apesar de a estratégia e-SUS Atenção Básica ser reconhecida como uma inovação tecnológica, predominam situações que fragilizam a sua aceitação como: incompatibilidades com o processo de trabalho; implantação de forma súbita, capacitação deficiente; sobrecarga de trabalho; resistências; e impactos negativos sobre a assistência. Conclusão: A difusão da estratégia e-SUS Atenção Básica como uma inovação tecnológica tem apresentado situações potencializadoras de sua rejeição, conformando-se como desafios a serem superados.

Descritores: Sistemas de Informação em Saúde; Difusão de Inovações; Atenção Primária à Saúde; Estratégia Saúde da Família; Informática em Enfermagem.

\section{RESUMEN}

Objetivo: Analizar la difusión de la innovación e-SUS Atención Primaria en Equipos de Salud de la Familia. Método: Estudio de caso de abordaje cualitativo, fundamentado en la Teoría de la Difusión de la Innovación y Modelo de Aceptación de Tecnologías. Se realizaron 62 entrevistas y observación de profesionales de Equipos de Salud de la Familia en seis municipios de Minas Gerais, entre marzo de 2016 y enero de 2017. Los datos fueron tratados a través del Análisis de Contenido Temático Categorial y, sistematizados, con el software Atlas.ti. Resultados: Se verificó que a pesar de que la estrategia e-SUS Atención Primaria es reconocida como una innovación tecnológica, predominan situaciones que debilitan su aceptación como: incompatibilidades con el proceso de trabajo; implantación de forma súbita, capacitación deficiente; sobrecarga de trabajo; resistencia; e impactos negativos sobre la asistencia. Conclusión: La difusión de la estrategia e-SUS Atención Primaria como una innovación tecnológica ha presentado situaciones potencializadoras de su rechazo, conformándose como desafíos a ser superados. 
Descriptores: Sistemas de Información en Salud; Difusión de Innovaciones; Atención Primaria de Salud; Estrategia Salud de la Familia; Informática en Enfermería.

\section{INTRODUCTION}

The Ministry of Health presents the e-SUS Primary Care (e-SUS PC - The e-SUS Basic Care (e-SUS AB) is a strategy of the Department of Primary Care to restructure the information of Primary Care at the national level) strategy as an innovation aimed at restructuring PC information throughout the Brazilian territory, through qualified computerization of SUS (Brazilian Unified Health System) ${ }^{(1)}$. With the e-SUS PC strategy, we seek to deploy two software systems for capturing citizens' health data: Simple Data Collection Planning (CDS - Coleta de Dados Simplificada) and Citizen's Electronic Record (PEC - Prontuário Eletrônico do Cidadão) ${ }^{(2)}$. In addition to the software systems, the availability of high-performance broadband internet access, computers and printers in all workstations interconnected with other points of the health care network ${ }^{(1)}$.

In fact, the e-SUS PC strategy represents possibilities for advancement and qualification in the use of information, but also challenges to be overcome. Some studies already demonstrate several weaknesses, compromising their legitimation and generating effects in the work process and in the professionals' daily life $\mathrm{e}^{(3-4)}$. In addition, the successful implementation of the e-SUS PC strategy also depends on its adoption by the various human actors involved, and in fact is adapted to a work process that takes place in the context of $\mathrm{PC}^{(5)}$.

This strategy implies structural changes in the ideals and practices of professionals and users of health services, thus becoming an innovation ${ }^{(1-6)}$, and it is necessary to evaluate their diffusion process. The process of diffusion of an innovation comprises its transmission in channels of communication between the members of a social system (individuals, groups or institutions) for a certain period of time ${ }^{(6)}$. Thus, the process of diffusing an innovation is crucial and determinant for its adoption or rejection by individuals/ adopters. This process starts individually based on the knowledge of innovation, which occurs in the implementation process ${ }^{(6)}$.

In the context of e-SUS PC innovation, there is a need to look at the process of its diffusion. In this sense, this research is justified because the process of implementing a technology per se is a complex process that will determine the effective adoption of the new technology or its rejection ${ }^{(6-9)}$. From these considerations, the guiding question of this study is defined: How has the diffusion of e-SUS PC innovation occurred in Family Health Teams in Minas Gerais Gerais State?

\section{OBJECTIVE}

This study aims to analyze the diffusion of e-SUS PC innovation in Family Health Teams.

\section{METOD}

\section{Ethical aspects}

The present research followed the guidelines of the National Health Council, and began after approval of the Ethics
Committee on Research in Human Beings with certificate of presentation for ethical appreciation of the Universidade Federal de São João Del Rei.

\section{Theoretical-methodological framework}

As a theoretical framework, the Innovation Diffusion Theory ${ }^{(6)}$ was used, in which every idea, action or object that represents change is conceived as an innovation. Moreover, the diffusion process of an innovation comprises the moment when the adopting subject becomes aware of the change and opts for its adoption or rejection ${ }^{(6)}$. There are elements that are capable of influencing the diffusion process, leading to adoption or rejection. The first, innovation, is measured from the attributes: Relative advantage (Perception that the use of innovation is advantageous); Compatibility (Perception that innovation is consistent with the needs of adopters); Observability (Results perceived by the adopters); Complexity (Ease or difficulty of innovation during its use); Experimentation (Innovation experienced by adopters prior to final deployment).

In the second element, communication channels, the means in which messages related to innovation circulate among individuals are identified. The third element is time, where the time between contact with innovation and the decision to accept or reject is measured. The fourth element, social system, identifies the members or units of a social system, being individual, informal groups or organizations.

In addition, we also use the Technology Acceptance Model ${ }^{(9)}$, where it is believed that the acceptance of a technology is linked to the perception of the subject under two dimensions: Perceived ease of use and perceived utility.

\section{Type of study}

This is a qualitative approach case study. Case studies are justifiable in specific situations as a peculiar circumstance or a revealing proposal ${ }^{(10)}$. The e-SUS PC strategy is a revealing proposal for the initial phase of deployment and use of its software systems. It was defined, as a unit of analysis, the diffusion of innovation e-SUS PC, and as context, the Family Health Teams.

The qualitative approach was justified by the need to understand a phenomenon that is linked to the subjectivity of the individual, its historicity and relations with the environment ${ }^{(11)}$. In this sense, the qualitative approach contributed to extract the meanings attributed by the participants in their experiences in the diffusion process of innovation e-SUS PC.

\section{Study setting}

The Health's Western region of Minas Gerais State was intentionally defined as setting, covering approximately 1,261,214 inhabitants and 54 municipalities. In order to collect data, all six municipalities that were the headquarters of the micro-region were included, due to the fact that they represented the largest municipalities and had better structural and resource conditions. This may denote scenarios 
favorable to the deployment of technology. In each of these municipalities a Family Health Team was selected, by random lottery that was going through the process of implanting the innovation. We emphasize that the selected teams started implementing the e-SUS PC strategy between January and March 2016.

\section{Data source}

As participants in the study, the professionals who had been involved in the Family Health Team for more than six months were involved in the implementation of the e-SUS strategy.

Professionals absent during the period of data collection for medical leave and vacations were excluded from the study. Of the 67 potential participants, 62 health professionals from the family health units were included: 6 doctors, 6 nurses, 7 nursing technicians, 4 dentists, 5 oral health technicians, 26 Community Health Agents (CHA), 5 administrative assistants, a psychologist, a physical educator, and a nutritionist. The heterogeneity of the study participants was justified by the need to capture the phenomenon from the perspective of the multiprofessional team working in the Family Health Strategy, in a work process that takes place in a team, and cannot be analyzed from the perspective of only a professional category. In addition, the implementation of the e-SUS PC strategy is a process that involves all professionals of the Family Health Team. The data were collected from March 2016 to January 2017.

\section{Collection and organization of data}

We used an interview with a semi-structured script in concomitance with the direct observation of the work routine of the professionals, according to an observation script. It is known that direct observation allows the study of the "case" in its real scenario and there is no impediment that the collection occurs in concomitance with the interview in the field ${ }^{(10)}$. Participants ${ }^{\prime}$ work routines were observed during the use of software systems (Simple Data Record or Citizen's Electronic Record), meetings where the implementation process was discussed, as well as situations (conflicts, debates, agreements, disagreements) that emerged in the field related to the diffusion process of innovation.

The observations were duly recorded in a field diary, generating Observation Notes (ON). The interviews were coded with the initials of the professional category, followed by the sequential interview and a code referring to the municipality. In this way, it follows the codification: DOC - doctor; NUR - nurse; NTE - nursing technician; PSY - psychologist; NUT - nutritionist; OHT - oral health technician; PHE - physical educator; PHA - pharmacist; SOW - social worker; CHA - Community Health Agent and ADM - administrative assistant. The municipalities were coded with the first six letters of the alphabet, for example: NUR24A. The interviews lasted an average of 50 minutes and the observation occurred during a typical work week (Monday to Friday), averaging 6 hours per day, in each of the Family Health Teams.

\section{Data analysis}

The data were analyzed through Content Analysis, ThematicCategorical modality ${ }^{(12)}$. In the first phase, the pre-analysis or floating reading was carried out: the first contact with the documents that consisted of analyzing and knowing the text, besides the preparation of the Observation Notes recorded in the field diary and the transcripts of the interviews, constituting the analytical corpus. In the second phase, the exploration of the material, its codification, was carried out. The registration units, the sense nuclei, the context units and, finally, the thematic categories were extracted. In the third phase, the results were treated in a way that was significant and valid. The analysis of the interviews, together with the material of the observations, articulated empirical data and theoretical references, seeking to answer the guiding question of the research. In order to systematize the organization and analysis of the data, the software Atlas.ti was used.

\section{RESULTS}

\section{The e-SUS PC innovation and its attributes}

Regarding the Relative advantage attribute, it was first recognized that the e-SUS PC strategy.

It gives more work to power the system because it has increased the amount of data details. (DOC33B)

On the other hand, it contributes to the follow-up of patients:

Now we have to follow up all hypertensive individuals, and all diabetics and put in the e-SUS, and perform a differentiated follow-up. (CHA16C)

Another advantage pointed out was the possibility of integrating the information with the other points of the care network:

The e-SUS is good out too [...] If a person suffers an accident, the professionals will open the system in the hospital and will have the data of that patient there, since it has already been registered here in the unit. (CHA24A)

The highlighted incompatibilities were:

There is something that the dentist does and sometimes there is no option to fill (OHT31B)

The concomitant use of other recording tools "I use more my laptop than e-SUS itself. Only if something is missing in my notebook, then I go after the e-SUS". (CHA22A)

In addition to duplicate typing and rework, everything is done twice, three times. This is what is terrible. If it were to do only on the computer, I would prefer to. (NTE32B)

The insufficient number of computers to access the information system was another situation pointed out:

We are two units, each enters its production, but it is a computer with only internet, it takes turns the schedules to be able to enter the production. (NUT29B)

There are also technical situations related to technology and connectivity that weaken its use:

I'm going to enter in the e-SUS, but cannot enter because it's off the air, at the end of the day we throw what is missing 
Diffusion of the e-SUS Primary Care innovation in Family Health Teams Silva TIM, Cavalcante RB, Santos RC, Gontijo TL, Guimarães EAA, Oliveira VC.

and if it stops for five days, it will be five days without entering. (NTE20A)

An internet that gets overwhelmed when everyone is trying to type. Because the internet does not support, it falls. (NUR34B)

For the attribute complexity, the difficulties to understand and use the software were related to the fact that the professionals do not understand the e-SUS PC strategy, besides an information system destined to the filing and recording of the production. (ON)

The incorporation of the e-SUS PC strategy proved to be a process to be added to the others, as one of the interviewees confirms:

It has everything we need to be archiving, keeping our production. (CHA13C)

And they simply understand it as a system of disseminating information to higher levels, not as support for local planning:

We are only compiling and supplying data to the Municipal Office, I do not analyze e-SUS data so I can schedule my agenda, we set up, last year a group of smokers looking for patients and not because e-SUS showed me [laughs]. (NTE09C)

The interviewees also highlighted the lack of ability with technologies:

They put a great system as is e-SUS, and sometimes, the person does not know how to tinker nor in Windows, does not know how to turn on the computer. (CHA02D)

My difficulty is to pick up the data and put it inside the computer. (CHA47F)

In addition, misunderstanding about software and its features is a limiting factor for access to consolidated data. The software is still a mystery for some health professionals:

It's been over a year now that we are in this struggle to implement the system [...] I needed a report of hypertensive, diabetic patients, I cannot. How will you program? How will you set agenda? [...] I do not know if it's because we do not know how to operate the system or if the system is really deficient. (NUR54E)

Regarding the experimentation, the interviewees recognized that the technology has been implemented:

In the day and day it is breaking the head, making mistakes, making right. (CHA02D)

In this context, training and support for use have been little resolute:

The training we had was on the part of the city hall [...], but in practice, even has not solved much. (OHT30B)

Regarding the results observed by the respondents, representing the attribute observability, some pointed to contributions of innovation:
Today I can see everything that was done by the patient. Sometimes the patient needs a consultation, of hypertensive and diabetic, depending on the degree if it is low risk or not, every four months. So I can see if he consulted or not and I call: Your John, why are not you scheduling your return? (NTE20A)

On the other hand, other participants stated:

Our assistance was hampered, because you have to allocate time for this [...] It is leaving much assistance to be desired. (NUR34B)

In one scene, a patient noticed the computerization and was bothered by the waiting time.

One user questioned about computerization reporting that she could witness the difficulty of one of the CHA's with the unit's receiving computer. The user complained about needing to wait a long time for service while two employees were busy with a computer. (ON)

The system's power demand has also caused some adjustments in the organization of the work with ethical implications related to the recording of information. Because professional secrecy, confidentiality of information and patient privacy may be compromised in this context:

It is not every professional that types his production, the doctor does not type, and then, the nurse ends up getting overwhelmed because he enters his and the doctor's. (NUR34B)

Such situation has caused inconsistencies in the records as reported below:

Whoever types my sheets is the secretary [...] she was having difficulty [...], I do a home visit every week and then visit home the code is 4, [...] six months later she came to me and said thus: 'Ours so-and-so, different code four'... are you doing a home visit?' She was entering the wrong code, everything had to be fixed. (DOC08C)

The great demand for powering the system has also generated some feelings in the professionals, which can be verified in the scene described and in the report of one of the professionals:

I could see the anguish and pain of a nurse through her facial expressions. Suffering sank into tears she tried to contain. That suffering had roots in the work relations affected since the implantation of the technology, such as the generated work overload, the concern with the reliability of the registered information and still the pressures of his superiors by the registry. $(\mathrm{ON})$

There were also those who showed resistance to innovation even in the face of the capabilities offered: [...] I started teaching one by one and taking the doubts out of each one, but two absorbs and four does not, a CHA has reached the point of saying that it will ask resignation not to have to use the computer. (NUR48F) 
Diffusion of the e-SUS Primary Care innovation in Family Health Teams Silva TIM, Cavalcante RB, Santos RC, Gontijo TL, Guimarães EAA, Oliveira VC.

\section{Communication channels involved in the diffusion of innovation}

It was found that some instances and technical artifacts that should have worked, such as communication channels, were unable to fulfill these responsibilities.

There are doubts that I have, because then the coordination also could not give me this support and the 136 also did not answer me. (NUR09C)

Regarding the regional superintendency, they stated:

The regional does not deal with solving things [...] there is no feedback. (NUR17A)

About the Municipal Office, they verbalized:

Nor do they know how to respond ... then they have to be contacting the person in charge to see if they can get any information. (CHA11C)

People stood out as the main channel of communication:

She [coordinator of the PHC of the municipality] runs the units, and sits and discusses the doubts, stayed the whole afternoon answering questions. (NUR09C)

The nurse was also reminded:

But if having any doubt, the nurse clarifies them. (CHA36B)

It was also observed that, professionals in the field of Informatics have played an important role in the support of the teams:

There's the guy from SEMUSA who works with the system, he gathered everyone and talked about e-SUS, showed on the computer. (DOC03D)

Influences of the social system and time in the diffusion of innovation

The interviewees signified the e-SUS from the need to meet the demands of the Municipal Office for transfer of funds:

The concern of people today is to enter the production so as not to leave the municipality to lose resource. (NUR34B)

Came from top to bottom, we know there are interests behind it. (DOC33B)

And the imposition of superior management spheres, triggering the inadequate and meaningless recording of their real importance:

We basically fulfill what the city hall requires [...] I honestly do not know why the city hall uses it here. (DOC08D)

The same happens with the structuring of the teams:

In fact, we've started not so much long ago. When we arrived, there was nothing computerized yet. (ADM18A)

The other interviewee reinforces:
It's a program that came all of a sudden [...] as it's still coming up now, it caught us by surprise with the change. (CHA36B)

\section{DISCUSSION}

In the innovation under analysis, its complexity was not predominantly in its difficulty of use, but in its understanding as a technology limited to the filing and recording of production, secondary to work and in which there is a lack of knowledge of the importance of adequate food. The innovation was also perceived as an imposition of management bodies, with related interests and related to the transfer of funds. Such situations have already been verified in other opportunities of implantation of information systems in the context of Brazilian public health ${ }^{(13-15)}$, reinforcing in the country an unsystematic, vertical, fragmented informational model that tends to develop the posture of data collection without meaning , and with little use in local planning and decision-making ${ }^{(13-15)}$.

It is important to highlight that these findings denote the recognition of technology as a tool of a work process with its own characteristics, influencing its use. It is known that the health work process, despite its intersubjective power, has its emphasis on technical success, where it is valued the production of numbers, indicators, goals and the standardization of care ${ }^{(16-17)}$. Technical capacity, in this context, characterizes, attempts to organize and discipline, as well as to disregard the critical action of individuals who construct work practices in relationships and encounters ${ }^{(16-17)}$. In this sense, the software systems of the e-SUS PC strategy end up endorsing this logic of the health work process, focusing on the fulfillment of normative ordinances, without reflection, limiting the understanding of technology as a viable tool for numbers and standards, more an element of bureaucratic paraphernalia.

Another situation verified was the way in which innovation has been diffused in the scenario investigated, suddenly, without a time destined to the experimentation of professionals and with deficiencies in the available technological infrastructure, which does not contribute to the acceptance and use of technologies ${ }^{(18)}$. On the one hand, there are charges of the Ministry of Health in the implantation, and on the other hand, the municipalities that lack infrastructure and other deficiencies, weakening the implantation. This is the representation of the asymmetries of management levels that end up characterizing the work process in health ${ }^{(19)}$. The success in the implantation of information technologies in the context of health depends on the recognition of this work process, its specificities, its adequate structuring and the involvement of the people ${ }^{(18,20)}$.

In addition, sufficient time must be allocated for structuring teams and organizing work processes. Imploring technology without experimentation, suddenly and without the involvement of people tends to potentiate the rejection of innovation ${ }^{(8,18)}$. The time in the diffusion process of innovation is of fundamental importance, because it understands the whole process of decision that will lead to the formation of an attitude towards the rejection or acceptance of innovation ${ }^{(8-9)}$. Moreover, the experimentation of innovation favors the creation of meanings, makes it possible to correct errors and increases the possibility of participation of people in their modifications, contributing to their acceptance ${ }^{(8)}$. It is worth emphasizing that there is a relational aspect in the health work process, where people, based 
on their social interactions, promote the practical success of the work, based on daily (re)inventions ${ }^{(16-17)}$. This time, people may or may not leverage the use of a technology, depending on the creation of meaning relevant to the work, where it does not represent a barrier to creativity, but ally in the solutions of problems. Thus, it is imperative that technological innovation be tried, reflected and criticized by the people, placed in favor of the professional, potentializing the practice of care.

Predominantly, incompatibilities of innovation were recognized with the daily work of professionals, making it difficult to perceive the usefulness of the system and the perception of ease of use. Such incompatibilities are characteristic of an information system that is still immature, in an initial phase of implementation, where information management is still based on records in paper ${ }^{(21)}$, and should be supplanted in order to enhance its adoption. In health systems where records are maintained in roles, as the basis of information management, it becomes difficult to systematize the assertive decision-making process, in addition to minimizing patient safety, placing the individual, their families and communities at risk assisted ${ }^{(15,18,20-21)}$.

It is imperative to rethink the collection and recording of information in the e-SUS strategy software systems in addition to the use of roles. It is necessary that professionals, whether at the user's home or in the family health units, already register the information directly in the system, through electronic registration devices. This has already been thought by the Brazilian government, as defined in the national plan for the implementation of the e-SUS PC strategy, which provides for the existence of computers and printers in all jobs, the availability of mobile electronic devices for home registration, and internet access and a stable connection ${ }^{(1)}$. However, in Brazil there is a considerable telecommunications deficit, in which access to the internet and connectivity are still barriers to the diffusion of technological innovations in the area of Health, due to the high costs and unfeasibility of the network ${ }^{(22)}$. In addition, in remote locations, such as rural areas, access to the internet is difficult and connection speed is lower than necessary, situations still typical in the Brazilian scenario ${ }^{(23)}$.

The participants also highlighted influences of innovation in the work of the teams, implying, predominantly, weaknesses. The work overload generated from the demand of the population registration, and the powering of the information system was perceived as a limitation to the work process in the services. This has weakened the time devoted to patient care and the prioritization of records on the care of some population groups to the detriment of others. Although the software systems of the e-SUS PC strategy favor the follow-up of the priority groups due to the individualisation of the records, an important advantage perceived in relation to other systems refers to the risk of their underutilization due to the overhead generated ${ }^{(3)}$. It is known that the overload generated by information systems also arises from its use as a bureaucratic tool, in which the importance of its data is unknown, and its operation is directed only to inform the higher instances about the production and reach of agreed goals ${ }^{(15)}$. Moreover, such overload has a negative repercussion on the perception of satisfaction of the use of the technology by professionals due to the time demanded to power the system ${ }^{(24)}$.

The great demand for powering the system has also generated ethical issues to be considered, since some professionals (non-doctors) end up assuming the typing of data generated by others (doctors) in the care of the users of the service. This situation refers to the breach of professional secrecy and disregards the maintenance of the privacy and confidentiality of the individuals' individual information. The concern is to value and defend the privacy of the individual in relation to their personal data, as well as the dissemination of information generated in the health care process ${ }^{(25)}$. The right to privacy and confidentiality of information encompasses intimacy, privacy, and the honor of persons, meaning that it is individuals themselves who have the right to decide on the maintenance of their information under their sole control, as they have the right to communicate to whom, when, where and under what conditions information must be disclosed ${ }^{(25)}$.

This division between doctors and non-doctors, where the former does not assume the power of the system, leaving this task to the other professionals, refers to the traditional social and technical division of the health work process ${ }^{(19)}$. The use of a technology is permeated by the characteristics of such a work process, as it is inherent in this context. So the ethical debate also revolves around this social and technical division of labor, where the doctor assumes a nuclear position ${ }^{(19)}$, empowered by the hegemonic social model focused on disease and cure. On the other hand, in a peripheral position ${ }^{(19)}$, there are those professionals who assume other practices, in support of medical work, and therefore it is up to these professionals to create means and agreements to record information of the medical professional.

Another negative effect of the diffusion of the e-SUS PC strategy observed were the feelings generated in professionals from the implementation of innovation. These are feelings that indicate resistance, suffering and conflicts in the face of the obligation to adopt a technology without proper preparation, without adequate infrastructure and disorganization of work processes. The implantation of technological innovations generally promotes resistance and discomfort to the adopters, especially when they represent an innovation that breaks with the processes/paradigms adopted previously. Such feelings should be considered and mitigated with a view to accepting innovation, since they are considered human factors influencing the success of an information system ${ }^{(26)}$.

Despite the negative effects of innovation, others were also perceived as contributing to the professionals' daily lives. These effects denote the potentialities of the technology for Primary Care and that need to be expanded and made effective as of its adoption by the professionals in order to plan and decide on the reality that presents itself in the Family Health Teams. It is noteworthy that despite the potential of the former Primary Care Information System (SIAB - Sistema de Informação da Atenção Básica) to be recognized, it was underutilized in the direction of local planning and decisions on patient's care ${ }^{(13,15)}$.

\section{Study limitations}

The study presents a limitation of its generalization capacity, as it is a case study of the Western region of Minas Gerais State, but its results may direct other investigations that deepen the understanding about the diffusion of technologies in health services and their repercussions on the relationships between professionals and patients. In addition, other investigations can be outlined, such as the analysis of the dissemination of the Citizen's Electronic Record 
Diffusion of the e-SUS Primary Care innovation in Family Health Teams Silva TIM, Cavalcante RB, Santos RC, Gontijo TL, Guimarães EAA, Oliveira VC.

(PEC/e-SUS PC), their influence on daily work, their acceptance by professionals, its effects on care management and on the work process. These themes were not addressed in this research, which was limited to analyzing only the diffusion of innovation.

\section{Contribution to the sector of Nursing}

The study brought contributions to the advancement of the Nursing area, especially in the thematic of Informatics in Nursing and evaluation of information technologies in health. Nursing professionals are undergoing the recent process of diffusion of the e-SUS PC strategy throughout the national territory, being their fundamental adoption for information management and qualification of care management. We advance in the knowledge about the potentialities and challenges that emerge from the diffusion of technological innovation, contributing to improve the adoption of technologies by nurses and other health professionals. In addition, as a recent computerization strategy of Primary Health Care in Brazil, there is still no studies with the theoretical approach used, describing the diffusion of innovation in evaluation. This situation endorses the contribution of this research to the advancement of knowledge in the context of Nursing and Health, in addition to reinforcing its novelty.

\section{FINAL CONSIDERATIONS}

The diffusion of the e-SUS PC strategy as a technological innovation has presented few potential situations of its acceptance, and predominantly, situations that are set as challenges to be overcome, as they potentiate their rejection. The initial integration and individualization of the information was emphasized as potentiators of the adoption/acceptance, thus contributing to the management of the assistance. However, aspects that have strengthened the rejection of innovation stand out: professionals have not yet recognized the e-SUS PC strategy as a tool for local planning and care management; the computerization of health units is still precarious and the use of technology faces resistance; professionals still need to develop technological skills; work overload still prevails with the deployment of technology.

\section{FUNDING}

The study was funded by the Coordination for the Improvement of Higher Education Personnel through process 404653/2016-2 and by the Fundação de Amparo à Pesquisa do Estado de Minas Gerais (FAPEMIG - APQ-00337-15).

\section{REFERENCES}

1. Brasil. Ministério da Saúde. Secretaria de Atenção à Saúde. e-SUS Atenção Básica: manual de implantação. Brasília: Departamento de Atenção Básica; 2014.

2. Paz LF, Maran V, Machado A, Augustin, I. MECA: Mobile System Support for Brazilian Community Health Agents Program Based on Context-Awareness. IEEE Latin America Transactions[Internet]. 2017[cited 2018 Jan 29];15(8):1547-55. Available from: https:// doi.org/10.1109/TLA.2017.7994805

3. Oliveira AEC, Lima IMB, Nascimento JA, Coelho HFC, Santos SR. Implantação do e-SUS AB no Distrito Sanitário IV de João Pessoa (PB): relato de experiência. Saúde Debate[Internet]. 2016[cited 2016 Sep 16];40(109):212-8. Available from: http://dx.doi. org/10.1590/0103-1104201610917.pdf

4. Astolfo S, Kehrig RT. O processo de implantação de uma estratégia integrada de SIS na APS no Mato Grosso, Brasil. Rev Saúde Colet UEFS[Internet]. 2017[cited 2018 Jan 29];7(1):8-15. Available from: http://periodicos.uefs.br/index.php/saudecoletiva/article/ view/1869/1273.pdf

5. Medeiros JB, Holmes ES, Albuquerque SGE, Santos SR. E-SUS Primary Care and simplified data collection: reports on implementation in a Family Health Strategy setting. Rev APS[Internet]. 2017[cited 2018 Jan 29];20(1):145-9. Available from: https://aps.ufjf.emnuvens. com.br/aps/article/view/2706.pdf

6. Rogers EM. Diffusion of innovation. 3ed. New York: The Free Press; 2003.

7. Davis FD. Perceived usefulness, perceived ease of use, and user acceptance of information technology. MIS Quarterly[Internet]. 1989[cited 2015 May 04];13(3):319-39. Available from: http://www.jstor.org/stable/249008.pdf

8. Holden RJ, Asan O, Wozniak EM, Flynn KE, Scanlon MC. Nurses' perceptions, acceptance, and use of a novel in-room pediatric ICU technology: testing an expanded technology acceptance model. BMC Med Inform Decis Mak[Internet]. 2015[cited 2016 Dec 12];16(145):1-10. Available from: http://dx.doi.org/10.1186/s12911-016-0388-y

9. Kern L, Barrón M, Dhopeshwarkar RV, Edwards A, Kaushal R. Electronic health records and ambulatory quality of care. J Gen Intern Med[Internet]. 2012[cited 2016 Nov 27];28(4):496-503. Available from: https://www.ncbi.nlm.nih.gov/pubmed/23054927

10. Yin R. Estudo de caso: planejamento e métodos. 5. ed. Porto Alegre: Bookman; 2015.

11. Minayo MCS. Qualitative analysis: theory, steps and reliability. Ciênc Saúde Colet[Internet]. 2012[cited 2017 May 24];17(3):621-6. Available from: http://dx.doi.org/10.1590/S1413-81232012000300007.pdf

12. Bardin L. Análise de conteúdo. 4. ed. Lisboa: Ed. 70, 2015.

13. Cavalcante RB, Pinheiro MMK, Guimarães EAA, Oliveira VC, Gontijo TL. Information system of primary care: beyond the technological improvements. Rev Enferm UFPE[Internet]. 2014[cited 2015 Sep 20];8(Suppl-1):2263-71. Available from: https://periodicos.ufpe. br/revistas/revistaenfermagem/article/download/9914/10191 
14. Cavalcante RB, Pinheiro MMK, Guimarães EAA, Miranda RM. An overview of the definition and implementation of the Brazililian National Policy on Health Data and Information Technology. Cad Saúde Pública[Internet]. 2015[cited 2017 Jan 03];31(5):960-70. Available from: http://www.scielo.br/pdf/csp/v31n5/0102-311X-csp-31-5-0960.pdf

15. Holmes ES, Santos SR, Almeida AF, Oliveira JHD, Carvalho GDA, Fonsêca LCT, et al. Health information systems in the decisionmaking process in primary care. Intern Arch Medicine Sect[Internet]. 2016[cited 2016 Sep 16];9(2). Available from: http://imed. pub/ojs/index.php/iam/article/view/1380.pdf

16. Schraiber LB. When a 'technical triumph' is deemed a 'practical success': the subject and the values of professional work in healthcare. Ciênc Saúde Colet[Internet]. 2011[cited 2018 Feb 26];16(7):3041-2. Available from: http://dx.doi.org/10.1590/ S1413-81232011000800003

17. Ayres JRCM. Cuidado: trabalho, interação e saber nas práticas de saúde. Rev Baiana Enferm[Internet]. 2017 [cited 2018 Feb 27];31(1):e21847. Available from: https://portalseer.ufba.br/index.php/enfermagem/article/view/21847

18. Nguyen L, Bellucci E, Nguyen LT. Electronic health records implementation: an evaluation of information system impact and contingency factors. Int J Med Inform[Internet]. 2014[cited 2016 Dec 13];83:779-96. Available from: http://dx.doi.org/10.1016/j. ijmedinf.2014.06.011

19. Gimenez CB, Marina P, Mesquita AJRC. Concepções e tipologia de conflitos entre trabalhadores e gerentes no contexto da atenção básica no Sistema Único de Saúde (SUS). Cad Saúde Pública[Internet]. 2014[cited 2018 Feb 26];30(7):1453-62. Available from: http://www.scielo.br/pdf/csp/v30n7/0102-311X-csp-30-7-1453.pdf

20. Ingebrigtsen T, Georgiou A, Clay-Williams R, Magrabi F, Hordern A, Prgomet M, et al. The impact of clinical leadership on health information technology adoption: systematic review. Int J Med Inform[Internet]. 2014[cited 2016 Nov 27];83:393-405. Available from: http://dx.doi.org/10.1016/j.ijmedinf.2014.02.005

21. Meeks DW, Takian A, Sittig DF, Singh H, Barber N. Exploring the sociotechnical intersection of patient safety and electronic health record implementation. J Am Med Inform Assoc[Internet]. 2014[cited 2016 Jul 14]:21:e28-e34. Available from: http://dx.doi. org/10.1136/amiajnl-2013-001762

22. Associação Brasileira de Pós-Graduação em Saúde Coletiva-Abrasco. Grupo Técnico de Informação em Saúde e População-GTISP. Plano Diretor para o desenvolvimento da Informação e Tecnologia de Informação em Saúde - PlaDITIS 2013-2017: no contexto da atual governança de informação e de implantação do Registro Eletrônico em Saúde/RES[Internet]. Brasília: ABRASCO; 2013[cited 2017 Apr 01]. Available from: http://www.abrasco.org.br/site/wp-content/uploads/ 2015/06/GT_informacao_plano-diretor.pdf

23. Oliveira F, Goloni-Bertollo EM, Pavario EC. The Internet as a source of health information. J Health Inform[Internet]. 2013[cited 2015 Jul 14];5(3):98-102. Available from: http://www.jhi-sbis.saude.ws/ojs-jhi/index.php/jhi-sbis/article/view/267.pdf

24. Babbott S, Manwell LB, Brown R, Montague E, Williams E, Schwartz M, et al. Electronic medical records and physician stress in primary care: results from the MEMO study. J Am Med Inform Assoc[Internet]. 2014[cited 2016 Dec 16];21(1):e100-e106. Available from: https://www.ncbi.nlm.nih.gov/pubmed/24005796.pdf

25. Saunders J. Confidentiality. Med J[Internet]. 2016[cited 2018 Jan 02];44(10):e596-e597. Available from: https://doi.org/10.1016/j. mpmed.2016.07.014

26. Farzandipur M, Jeddi FR, Azimi E. Factors affecting successful implementation of hospital information systems. Acta Inform Med[Internet]. 2016[cited 2016 Feb 02];24(1):51-5. Available from: http://dx.doi.org/10.5455/aim.2016.24.51-55 